\title{
HANGING THE BEEF CARCASS BY THE FOREQUARTER TO IMPROVE TENDERNESS OF THE LONGISSIMUS DORSI AND BICEPS FEMORIS MUSCLES
}

\author{
Albino Luchiari Filho ${ }^{*}$; Renato Prates Macedo²; Angélica Simone Cravo Pereira ${ }^{1}$; Saulo da \\ Luz e Silva ${ }^{1}$; Paulo Roberto Leme ${ }^{1}$; Guilherme Feitosa ${ }^{1}$ \\ ${ }^{1}$ USP/FZEA - Depto. Zootecnia, C.P. 23 - 13635-900 - Pirassununga, SP - Brasil. \\ ${ }^{2}$ Marfrig Frigorificos e Comércio de Alimentos Ltda - Via de acesso Dr. Shuhei Uetsuka, km 02 - 16370-000 - \\ Promissão, SP - Brasil. \\ *Corresponding author <luchiari@usp.br>
}

\begin{abstract}
Hanging beef carcasses in different configurations in the cooler affect some carcass muscle tenderness. Forty Nellore steer carcasses (ten per day) were chosen at random in a federally inspected slaughter plant and hanged alternate left and right sides either in the traditional way by the hindquarter (HQ) or by the forequarter (FQ) also called "tenderbife". Carcasses were selected from steers up to 30 months old and had an average hot carcass weight of $244.1 \mathrm{~kg}$. These carcasses were chilled for 48 hours, when samples from the Longissimus dorsi (LD) at the $12^{\text {th }}$ rib and the Biceps femoris (BF) at the P8 site were removed, kept under refrigeration $\left(0-2^{\circ} \mathrm{C}\right)$ for five days and frozen for future analysis. The temperature of the LD after 24 hours taken at the $12^{\text {th }}$ rib was not different for HQ $\left(1.0^{\circ} \mathrm{C}\right)$ and FQ $\left(0.9^{\circ} \mathrm{C}\right)$. Fat thickness measured at the $12^{\text {th }}$ rib was lower $(P<0.05)$ for HQ $(3.8 \mathrm{~mm})$ than FQ $(4.3 \mathrm{~mm})$. All samples were thawed during 48 hours under refrigeration for tenderness evaluation. Warner Bratzler Shear force from the LD was lower $(P<0.001)$ for FQ $(3.53 \mathrm{~kg})$ than HQ $(4.78 \mathrm{~kg})$ and was not different for BF. Total cooking losses were not different between HQ $(19.7 \%)$ and FQ $(18.9 \%)$. Hanging beef carcass by the forequarter caused an improvement in tenderness of the LD without any detrimental effect on the BF (cap of rump).

Key words: beef cattle, carcass suspension, meat quality, tenderness
\end{abstract}

\section{SUSPENSÃO DA CARCACA PELO DIANTEIRO PARA MELHORAR A MACIEZ DOS MÚSCULOS LONGISSIMUS DORSI E BICEPS FEMORIS}

\begin{abstract}
RESUMO: A suspensão da carcaça em diferentes formas na câmara fria influencia a maciez de alguns músculos da carcaça. As carcaças de 40 novilhos Nelore (dez por dia) com no máximo 30 meses de idade foram selecionadas ao acaso em frigorífico (SIF 2543) e lados alternados de suas carcaças foram resfriados e pendurados pelo Tendão de Aquiles do traseiro especial (TA) ou pelo músculo carpo radial dianteiro (DA), também chamado "tenderbife". Todas as carcaças eram de classificação B no Sistema Brasileiro de Tipificação de Carcaças, com média de peso de carcaça quente de 244,1 kg. O pH 24 horas não diferiu para os tratamentos, $(\mathrm{TA}=5,69$ e DA $=5,70)$. As carcaças foram resfriadas por 48 horas e a seguir, amostras do Longissimus dorsi (LD) na altura da $12^{\underline{a}}$ costela e Biceps femoris (BF) na altura do sítio P8 foram removidas, mantidas sob refrigeração $\left(0-2^{\circ} \mathrm{C}\right)$ por mais 5 dias e a seguir congeladas para posterior análises. A espessura de gordura medida na altura da $12^{\text {a }}$ costela foi menor $(P<0,05)$ para TA $(3,8 \mathrm{~mm})$ do que DA $(4,3 \mathrm{~mm})$. A força de cisalhamento do músculo LD foi menor $(P<0,01)$ para o DA $(3,53 \mathrm{~kg})$ do que para o TA $(4,78 \mathrm{~kg})$ e não foi estatisticamente diferente para o músculo BF. As perdas totais ao cozimento também não foram estatisticamente diferentes $(\mathrm{TA}=19,7 \%$ e $\mathrm{DA}=18,9 \%)$. O resfriamento da carcaça pendurada pelo dianteiro ocasionou uma melhoria significativa na maciez do músculo LD (contra-filé) sem causar um efeito indesejável no músculo BF (picanha).

Palavras-chave: bovinos, suspensão da carcaça, qualidade da carne, maciez
\end{abstract}

\section{INTRODUCTION}

There is a segment of consumers willing to pay a premium for guaranteed tender beef, however inconsistent meat tenderness has been identified as one of the major problems facing the meat industry nowadays (Shackelford, et al., 2001).
Meat quality is affected by many factors as tenderness, juiciness and flavor, all contributing to the overall liking/disliking consumer attitude. Tenderness is the main quality attribute of beef, and the main reason for consumers buying and consuming it (Cia \& Corte, 1978). Also tenderness is responsible for $40 \%$ of consumer acceptance of meat, followed by overall liking responding 
for $30 \%$, flavor for $20 \%$ and juiciness for $10 \%$ (Chapell, 2001). As meat tenderness is one of the most important organoleptic trait for the consumer, a possible solution for improving tenderness of Bos indicus meat, would be using methods as electric stimulation, cooler management, ageing, injection of calcium chloride or carcass suspension by pelvic bone (Pedreira et al., 1999).

Eventually the beef processing segment of meat industry will adopt technologies to sort out carcasses for tenderness. The percentage of carcasses qualifying for "tender" needs to be as high as possible to assure the system success whatever it is. Thus, it would benefit the processor to implement as many steps as feasible to improve tenderness before the classification occurs. In addition, a processor might want to implement specifications for cattle to be slaughtered that includes production practices that could potentially improve meat tenderness. Hanging carcasses in different configurations in the cooler, through stretching certain muscles and relaxing others, has been suggested to increase tenderness of stretched muscles and decrease tenderness of relaxed muscles (Owens \& Gardner, 1999).

Reviewing the literature about some aspects of feedlot management and nutrition on carcass measurements, Owens \& Gardner (1999) reported that Longissimus muscle shear force tended to improve as carcass weights increased, perhaps associated with greater stretch of the Longissimus muscle with greater carcass weight. Tenderstretching is an alternative carcass hanging configuration in which the carcasses are hanged by pelvic bone. This physical process increases tension over loin and hindquarter muscles during rigor establishment avoiding intense contraction and turning them more tender (Forrest et al., 1979). In zebu steers, accordingly to Norman \& Cia (1980), apllying the tenderstretch increased tenderness of the Gluteus medius, Quadriceps femoris and Biceps femoris but no improvement was observed for the Longissimus dorsi, and increased the sarcomere length of all muscles studied but the Psoas major. Nevertheless, although tenderstretch was proved to be effective in improving tenderness, it has the disadvantage of hind leg hanging in a $90^{\circ}$ position, which may require additional floor space for the carcasses or sides in the chilling rooms (Sorheim \& Hildrum, 2002) which difficult its adoption.

In the early 1990's, a new method for muscle stretching or restraining major muscles in carcasses called tendercut was introduced by scientists at Virginia Polytechnic Institute and State University. The procedure for the tendercut implies making cuts in the skeleton of the pre rigor carcass shortly after slaughter while maintaining the Achilles tendon suspension (Claus, 1994). However, the tendercut requires more work than the tenderstretch, and the round/sirloin cut seems to be dependent on well-defined criteria for the specific cutting
(Sorheim \& Hildrum, 2002). Herring et al. (1967) studying the effects of various degrees of stretching or shortening on tenderness and sarcomere length of Semitendinosus muscle concluded that it was more important to prevent shortening than to ensure maximal stretch.

Our hypothesis is that hanging carcasses by forequarter could have an impact over tenderness of some muscles, since it reduces tension in muscles of loin and hindquarter. In this way, the objective of this work was to study the effect of hanging carcasses by forequarter on tenderness of the Longissimus dorsi (striploin) and Biceps femoris (cap of rump) muscles.

\section{MATERIAL AND METHODS}

During four consecutive days 40 commercial Nellore steers carcasses (ten per day) were random selected in a federal inspected packing plant (Promissão, SP, Brazil). The mean and standard error of hot carcass weight and fat thickness were $244 \pm 3.1 \mathrm{~kg}$ and $4.1 \pm 0.19$ $\mathrm{mm}$, respectively, and animals were up to 30 months old. Alternate sides of these carcasses were hanged by the traditional Aquilles tendon method (HQ) while the opposite side was hanged by the Carpi radialis muscle (FQ), and chilled during 24 hours in a cooler with temperature between $0-2^{\circ} \mathrm{C}$ when temperature and $\mathrm{pH}$ measurements of Longissimus dorsi muscle (LD) were taken with a digital $\mathrm{pH}$ meter.

After 48 hours of chilling one inch thick samples of $\mathrm{LD}$ between the $12-13^{\text {th }}$ ribs and the Biceps femoris muscles (BF) at the P8 site (pelvic portion of the Biceps femoris over the Gluteus medius muscle) were taken, individually labeled, vacuum packaged and aged during 5 days $\left(0-2^{\circ} \mathrm{C}\right)$. Immediately before samples were cut fat thickness over LD was measured at three quarters of medial end. After ageing, samples were frozen for posterior shear force measurement. Shear force was determined using a Warner Bratzler equipment according methodology described by Wheeler et al. (2001). Also were determined total cooking losses by weight difference of steaks before and after cooking. Data were analyzed as paired measurements and $T$ test was used to detect differences between treatments by the Univariate procedure of $S_{A S}{ }^{\circledR}$ software (SAS Institute Inc., Cary, NC, USA).

\section{RESULTS AND DISCUSSION}

There were no differences in carcass temperature or $\mathrm{pH}$ measured 24 hours after slaughter (Table 1). Nevertheless fat thickness was greater $(P=0.03)$ in carcasses hanged by forequarter $(4.3 \mathrm{~mm})$ than those by hindquarter $(3.8 \mathrm{~mm})$. This difference could be due to a reduction in tension on the Longissimus dorsi which would, causes a shortening of the muscle and fat, increasing its thickness. 
Table 1 - Means, standard errors and probabilities $(P)$ of carcass characteristics hanged by the hindquarter or forequarter.

\begin{tabular}{|c|c|c|c|c|}
\hline \multirow{2}{*}{ Characteristic } & \multicolumn{2}{|c|}{ Method of hanging } & \multirow{2}{*}{$\begin{array}{c}\text { Standard } \\
\text { error of mean }\end{array}$} & \multirow{2}{*}{$P$ value } \\
\hline & Hindquarter & Forequarter & & \\
\hline Temperature $24 \mathrm{~h},{ }^{\circ} \mathrm{C}$ & 1.0 & 0.9 & 0.29 & 0.10 \\
\hline $\mathrm{pH} 24 \mathrm{~h}$ & 5.69 & 5.70 & 0.02 & 0.30 \\
\hline Fat thickness, mm & 3.8 & 4.3 & 0.26 & 0.03 \\
\hline Longissimus dorsi shear force, $\mathrm{kg}$ & 4.78 & 3.53 & 0.13 & $<.01$ \\
\hline Biceps femoris shear force, $\mathrm{kg}$ & 3.61 & 3.52 & 0.14 & 0.58 \\
\hline Total cooking losses, $\%$ & 19.7 & 18.9 & 0.83 & 0.44 \\
\hline
\end{tabular}

Warner Bratzler shear force from the LD was lower $(P<0.01)$ for carcasses hanged by forequarter than for hindquarter while $\mathrm{BF}$ shear force and total cooking losses were not affected by treatment. Although many studies in the literature report effects of different methods of carcass hanging on tenderness of beef muscles, none of them studied the effect of forequarter carcass suspension and its effect on tenderness. Hanging carcass by pelvic bone (tenderstretching) has been reported as improving tenderness in beef carcasses, since it increases tension over loin and hindquarter muscles, avoiding intense contraction of muscles turning them tender (Sorheim et al., 2001).

Cold shortening and subsequent toughness of meat can be reduced by either slow or delayed pre rigor chilling, by electrical stimulation to speed up glycolysis resulting in rigor mortis to occur faster at a higher temperature in the meat, or by physically stretching or restricting the muscle to contract. These tenderizing treatments can be used on a single basis or in combinations (Sorheim \& Hildrum, 2002). The effect of carcass suspension methods on sarcomere length and shear force of some bovine muscles was examined by Hostetler et al. (1972). Carcasses were suspended vertically by the Achilles tendon, horizontal, neck-tied, hip-tied and hip-free by obturator foramen in the pelvic or aitch bone. Shear force was greater in LD of carcasses suspended vertically by Achilles tendon compared to other methods, but carcasses suspended horizontally, neck-tied, hip-tied and hip-free were not different.

A comparison of various muscles from beef carcass which entered rigor either in a horizontal position with the limbs perpendicular to the vertebrae or in the common vertical position by the Achilles tendon suspension, Herring et al. (1965) observed that horizontally placed sides resulted in longer sarcomeres, lower fiber diameters and increased tenderness of Longissimus, Gluteus medius, Biceps femoris and Semimenbranosus. In a study conducted to determine how the tenderness of a single muscle varies when submitted to different degrees of shortening or stretching, Herring et al. (1967), stretched or contracted samples of Semitendinosus muscle by $12,24,36$ or $48 \%$ of the pre-excised length. Accord- ing to the results, the difference in tenderness of muscles stretched $12-48 \%$, although apparent, was not of the magnitude verified with the various stages of shortening. The authors concluded that from the standpoint of ultimate tenderness, it is more important to prevent postmortem shortening than to ensure maximal stretch.

Although not evaluated in this work, an increase in diameter and a decrease in length was noticed in all major muscles of the hindquarter, what could partially explain the thicker fat layer for the forequarter hanged treatment. The studies accomplished by Bouton et al. (1973) confirmed findings of increased tenderness of Longissimus, Semimembranosus and Gluteus medius muscles by tenderstrech, with tenderness values of nonaged meat equivalent to 21 days ageing. Moreover, in addition to increasing the average tenderness level, tenderstretch had the ability to reduce the variation in tenderness of beef Longissimus muscles (Sorheim et al., 2001). Nevertheless, the tenderizing effect of muscle like Biceps femoris, Semimembranosus and Psoas major was none or slight (Sorheim \& Hildrum, 2002). It is probably due to the high content of sinew and connective tissue, which determine the tenderness more than the possible stretching of the myiofibrillar proteins. The degree of contraction in which a muscle enters the state of rigor is variable among different muscles (Locker, 1960) and, accordingly to Shanks et al. (2002) these differences among muscles may be influenced by the proximity of the individual muscle in relation to skeletal separation point and muscle fiber orientation in relation to tension.

Hanging the beef carcass by the forequarter caused a significant improvement in tenderness of the LD without any detrimental effect on the BF. This improvement in tenderness could be due to suspension of carcasses by forequarter. Despite of reducing tension on Longissimus dorsi muscle it seems that it was sufficient to avoid muscle shortening. These results suggest that the physical treatment, "tenderbife", has altered the environment in the myofiber affecting the rates of certain biochemical activities. Additional studies of biochemical events, such as, sarcomere lengths and myofibrillar fragmentation index of raw myofibrils need to be done. 


\section{REFERENCES}

BOUTON, P.E.; HARRIS, P.V.; SHORTHOSE, W.R.; BAXTER, R.I. A comparison of the effects of ageing conditioning and skeletal restraint on the tenderness of mutton. Journal of Food Science, v.38, p.932937, 1973.

CIA, G.; CORTE, O. O. A influência da velocidade de resfriamento na maciez da carne bovina. In: SEMINÁRIO NACIONAL DE ARMAZENAMENTO, 3., 1978, Curitiba. Proceedings. Curitiba, 1978.

CLAUS, J.R. The Tendercut ${ }^{\mathrm{TM}}$ process. In: MEAT INDUSTRY RESEARCH CONFERENCE, 1994. Proceedings. Chicago: American Meat Institute Foundation, 1994. p.101-113.

CHAPELL, G. The importance of marbling in the domestic market - what does it means for consumers? In: BEEF QUALITY CRC MARBLING SYMPOSIUM, Coffs Harbour, 2001. Proceedings. Coffs Harbour, 2001, p.30.

FORREST, J.C.; ABERLE, E.D.; HEDRICK, H.B.; JUDGE, M.D.; MERKEL, R.A. Fundamentos de Ciência de la Carne. Zaragoza: Editorial Acribia, 1979. 364p.

HERRING, H.K.; CASSENS, R.G.; BRISKEY, E.J. Further studies on bovine muscle tenderness as influenced by carcass position, sarcomere length, and fiber diameter. Journal of Food Science, v.30, p.132-135, 1965.

HERRING, H.K.; CASSENS, R.G.; SUESS, G.G.; BRUNDGART, V.H.; BRISKEY, E.J. Tenderness and associated characteristics of stretched and contracted bovine muscles. Journal of Food Science, v.32, p.317323, 1967.

HOSTETLER, R.L.; LINK, B.A.; LANDMANN, W.A.; FITZHUGH JR., H.A. Effect of carcass suspension on sarcomere length and shear force of some major bovine muscles. Journal of Food Science, v.37, p.132135, 1972.

LOCKER, R.H. Degree of muscular contraction as a factor in tenderness of beef. Food Research, v.25, p.304-307, 1960.
NORMAN, G.A.; CIA, G. The influence of carcass position during rigor on the tenderness of bovine muscles from mature zebu animals. Tropical Science, v.22, p.287-296, 1980.

OWENS, F.N.; GARDNER, B.A. A review of the impact of feedlot management and nutrition on carcass measurements of feedlot cattle. In: ANNUAL MEETING OF AMERICAN SOCIETY OF ANIMAL SCIENCE, Indianapolis, 1999. Proceedings. Indianapolis: Indianapolis Convention Center, 1999. 18p.

PEDREIRA, A.C.M.S.; LUCHIARI FILHO, A.; NARDON, R.F.; RAZOOK, A.G. Efeito da injeção de cloreto de cálcio pós-morte e tempo de maturação, no amaciamento e perdas por cozimento do músculo Longissimus dorsi de animais Bos indicus e Bos taurus selecionados para ganho de peso. Revista Brasileira de Zootecnia, v.28, p.13821389, 1999.

SHACKELFORD, S.D.; WHEELER, T.L.; MEADE, M.K.; REAGAN, J.O.; BYRNES, B.L.; KOOHMARAIE, M. Consumer impressions of tender select beef. Journal of Animal Science, v.79, p.2605-2614, 2001.

SHANKS, B.C.; WULF, D.M.; REUTER, B.J.; MADDOCK, R.J. Increasing tenderness of beef round and sirloin muscles through prerigor skeletal separations. Journal of Animal Science, v.80, p.123-128, 2002.

SORHEIM, O.; IDLAND, J.; HALVORSEN, E.C.; FROYSTEIN, T.; LEA, P.; HILDRUM, K. Influence of beef carcass stretching and chilling rate on tenderness of m. Longissimus dorsi. Meat Science, v.57, p.79-85, 2001.

SORHEIM, O.; HILDRUM, K.I. Muscle stretching techniques for improving meat tenderness. Trends in Food Science \& Technology, v.13, p.127$135,2002$.

WHEELER, T.L.; SHACKELFORD, S.D.; KOOHMARAIE, M. Shear force procedures for meat tenderness measurement. Roman L. Hruska U.S. Marc. USDA, Clay Center, NE, 2001.

Received November 04, 2004

Accepted July 19, 2005 